\title{
Healthcare Workers' Workplace Readiness during COVID-19 Pandemic in Northern India: A Cross-sectional e-Survey
}

\author{
Suresh K Sharma ${ }^{1}$, Mahendra K Saini ${ }^{2}$, Sachin Dwivedi ${ }^{3}$, Shelly Dhawan ${ }^{4}$, Anindita Mandal ${ }^{5}$
}

\begin{abstract}
Background: There is a high risk for healthcare workers (HCWs) to get infected with severe acute respiratory syndrome coronavirus 2 (SARSCoV-2) during the ongoing pandemic, which may last for many months. Inadequate preparedness of the healthcare delivery system, such as shortage of personal protective equipment (PPE), lack of hand hygiene facilities, insufficient manpower capacity building may compromise the safety of HCWs and quality of care. Therefore, it is essential to ensure efficient workplace readiness for the HCWs for their safety and thereby the continued quality of care.

Materials and methods: A cross-sectional web-based survey was conducted to assess workplace preparedness at healthcare facilities in northern India, especially the availability of PPE, HCWs capacity building, and mitigation effort taken by institutions. A 20-item structured, prevalidated questionnaire was circulated among nurses, doctors, premedical, and other categories of healthcare workers deployed at different level of healthcare facilities in conveniently selected states of northern India. This web-based survey was conducted during the month of April-June 2020, where 1,218 HCWs voluntarily participated.

Results: Out of 1,218 participants, the majority of them reported adequate supply of PPE (804; 66\%), availability of sufficient hand hygiene facility $(802 ; 65.8 \%)$, organization of capability building and upskilling training program on COVID-19 for them (896; 73.6\%), and perceived institute's excellent to good level of support while working with patients of COVID-19 (890; 73.1\%).

Conclusion: There was provision of adequate PPE, infection control facilities, upskilling of HCWs, and support system for the healthcare warriors in northern India to maintain adequate safety of HCWs and functionality of the healthcare system in this crucial time.

Keywords: COVID-19, Healthcare workers, Pandemic, Workplace readiness.

Pondicherry Journal of Nursing (2020): 10.5005/jp-journals-10084-12163
\end{abstract}

\section{INTRODUCTION}

Novel coronavirus, SARS-CoV-2 has resulted in the outbreak of a respiratory illness worldwide. It has been declared as a pandemic within a very short period of time from its first case detection at Wuhan, China on 31st December, 2019.1,2 Globally, 216 countries and territories has counted with 74.1 lac COVID-19 positive cases and 4.18 lac death till June 14,2020, because of its highly contagious nature of this virus. ${ }^{3}$ Healthcare workers are more vulnerable to get infected as they are toiling a countless number of hours for providing care of positive one. ${ }^{4}$ National Health Commission of China had released the figures about more than 3,300 healthcare professionals infected in March, causing at least 46 deaths as of 17 March, 2020. ${ }^{5}$ Inadequate readiness of the present healthcare system to impede COVID-19 transmission and recovery of infected one makes the scenario more devastating for frontline corona warrior of healthcare service. Shortage of workforce (doctor, nurses), poor infrastructure, and scanty resources e.g., personal protective equipment (PPE), ventilators, medicines, training program along with fear of getting infected are the factors which have made the pandemic as the biggest challenge to HCWs. ${ }^{6,7}$ The European Respiratory Society has already urged the European Union and national governments to prioritize health and safety of the frontline fighters against COVID19. ${ }^{8}$ Twenty percent of healthcare workers in the United Kingdom (UK) were more likely to quit their job after the pandemic, unless immediate action to be taken regarding their safety and required facilities. ${ }^{9}$ All necessary steps associated with decreasing rate of COVID-19 infection include, covid testing of frontline healthcare staffs as a priority, integrated training for healthcare workers, availability of PPE, proper hand hygiene practices, isolation and
${ }^{1-5}$ College of Nursing, All India Institute of Medical Sciences, Dehradun, Uttarakhand, India

Corresponding Author: Suresh K Sharma, College of Nursing, All India Institute of Medical Sciences, Dehradun, Uttarakhand, India, Phone: +918475000293, e-mail: sk.aiims17@gmail.com

How to cite this article: Sharma SK, Saini MK, Dwivedi S, Dhawan S, Mandal A. Healthcare Workers' Workplace Readiness during COVID-19 Pandemic in Northern India: A Cross-sectional e-Survey. Pon J Nurs 2020;13(3):54-59.

Source of support: Nil

Conflict of interest: None

quarantine protocols to follow, appropriate psychological measures for HCWs should be implemented. ${ }^{4,10}$ Therefore, the Ministry of Health and Family Welfare is already working on the development of a virtual training platform for capacity building in healthcare workers involved in the care of COVID-19 in India. ${ }^{11}$ Though global health systems showed gross unreadiness for such pandemic, leaving some of the HCWs as casualties but it should be the prime responsibility of every institution to make sure the healthcare worker's safety during the emergency. ${ }^{12}$ Therefore the aim of the present study is to assess workplace preparedness and mitigation measures taken for healthcare workers against SARS-CoV-2 in northern India.

\section{Materials and Methods}

This cross-sectional, structured questionnaire-based online survey was carried out using Survey Monkey@ during the months of April- 
June 2020. The survey participants were enrolled using a convenient sampling technique and participants who have not assigned duties in COVID-19 units or not willing to participate in the study were excluded. A total of 1,500 conveniently selected healthcare workers deployed in COVID-19 wards/units of select primary, secondary and tertiary level healthcare facility situated in select states of northern India were contacted to participate this research project; out of them, 1,218 (81.2\% response rate) have responded and completed survey proforma.

The research project was approved by the Institutional Ethics Committee of AlIMS, Rishikesh. Confidentiality of the study participants was maintained throughout the study by keeping the information anonymous. A web-based, informed, written voluntary consent was obtained from each study participant.

Although it is necessary to estimate adequate sample size to provide reliable results, which can provide a strong basis for recent evidence, ${ }^{9}$ but in the present study we did not restrict the number of health facilities and the number of participants because it was a multicenter online survey. Furthermore, a large-sample survey provides more accurate and generalizable results.

A self-structured questionnaire was prevalidated by five experts and was also circulated among 50 healthcare workers to assess the clarity, relevance, and acceptability of the items. The final draft of the questionnaire consisted of a total of 20 items related to the readiness of HCWs' workplace readiness to deal with COVID-19 pandemic. Finally, the structured questionnaire was distributed to conveniently selected participants through web-link using Survey Monkey $\odot$ to record the responses regarding demographic and work profile of participants (such as age, gender, designation, type and level of healthcare setting and working area) and items related to workplace preparedness (such as the source of information about COVID-19, received training for empowering knowledge, hand hygiene facilities, perceived workload, availabilities of PPEs and safety measures, perceived support from the institute and management strategies).

Data were coded and then entered to excel sheets and Statistical Package for the Social Sciences (SPSS 23.0) was used for statistical analysis. Data were analyzed using descriptive (frequency, percentage, measures of central tendency and measures of dispersion), and inferential statistics (Chi-squared).

\section{Results}

The mean age of healthcare workers was $29.07 \pm 5.12$ where almost half of the healthcare workers $(54.4 \%)$ were male. The majority of the participants were nursing officers (79.8\%), belonged to the government healthcare setting (79.4\%), and were working at tertiary care institutes (65.1\%). About the area of COVID-19 care, $31.6 \%$ of HCWs were working in the isolation ward, $25.3 \%$ in the triage/emergency area, and $23.6 \%$ in outpatient department (OPD) service. Moderate workload was reported by the majority of healthcare workers (41.7\%) and most of the professionals (78.32\%) did not express fear while working on patients suffering from SARS-CoV-2 (Table 1).

Workplace preparedness of healthcare workers during COVID-19 pandemic was categorized under some subheadings e.g., source of information about COVID-19, available hand hygiene facility, received training for infection prevention and empowering COVID-19 knowledge, support received from the institute while working with COVID-19 patients, availability of PPE in the clinical area, etc. As per the present study, $65.8 \%$ of HCWs had received
Table 1: Demographic and working profiles of Healthcare professionals working with COVID-19 patients $(n=1,218)$

\begin{tabular}{|c|c|c|c|c|}
\hline \multirow{2}{*}{$\begin{array}{l}\text { Variables } \\
\text { Age (in } \\
\text { years) }\end{array}$} & & \multirow{2}{*}{$\frac{\text { Mean }+S D}{29.07 \pm 5.12}$} & \multirow{2}{*}{$\begin{array}{l}\text { Minimum } \\
19\end{array}$} & \multirow{2}{*}{$\begin{array}{l}\text { Maximum } \\
56\end{array}$} \\
\hline & & & & \\
\hline & & Frequency & & Percentage \\
\hline & Male & 662 & & 54.4 \\
\hline & Female & 556 & & 45.6 \\
\hline \multirow[t]{4}{*}{ Designation } & Doctor & 129 & & 10.5 \\
\hline & $\begin{array}{l}\text { Nursing } \\
\text { officer }\end{array}$ & 972 & & 79.8 \\
\hline & Technician & 80 & & 6.5 \\
\hline & $\begin{array}{l}\mathrm{CHO} / \mathrm{NP} / \\
\mathrm{ASHA} / \mathrm{HA}\end{array}$ & 37 & & 3.2 \\
\hline \multirow{2}{*}{$\begin{array}{l}\text { Type of } \\
\text { healthcare } \\
\text { setting }\end{array}$} & Government & 967 & & 79.4 \\
\hline & Private & 251 & & 20.6 \\
\hline \multirow{3}{*}{$\begin{array}{l}\text { Level of } \\
\text { healthcare } \\
\text { facility }\end{array}$} & $\begin{array}{l}\text { Tertiary care } \\
\text { hospital }\end{array}$ & 793 & & 65.1 \\
\hline & $\begin{array}{l}\text { Secondary } \\
\text { care hospital }\end{array}$ & 269 & & 22.1 \\
\hline & $\begin{array}{l}\text { Primary care } \\
\text { hospital }\end{array}$ & 156 & & 12.8 \\
\hline \multirow[t]{7}{*}{$\begin{array}{l}\text { Area of } \\
\text { work }\end{array}$} & $\begin{array}{l}\text { Emergency/ } \\
\text { triage }\end{array}$ & 308 & & 25.3 \\
\hline & OPD & 288 & & 23.6 \\
\hline & Isolation ward & 385 & & 31.6 \\
\hline & OT & 33 & & 2.7 \\
\hline & ICU/CCU/HDU & 64 & & 5.3 \\
\hline & Ward & 118 & & 9.7 \\
\hline & $\begin{array}{l}\text { Others (CHC, } \\
\text { Lab, HWC, } \\
\text { Management, } \\
\text { community) }\end{array}$ & 22 & & 1.8 \\
\hline \multirow[b]{2}{*}{$\begin{array}{l}\text { Fears and } \\
\text { concerns } \\
\text { while } \\
\text { working } \\
\text { with } \\
\text { COVID-19 } \\
\text { patients }\end{array}$} & Yes & 264 & & 21.67 \\
\hline & No & 954 & & 78.32 \\
\hline \multirow{4}{*}{$\begin{array}{l}\text { Perceived } \\
\text { workload } \\
\text { while } \\
\text { working } \\
\text { with } \\
\text { COVID-19 } \\
\text { patients }\end{array}$} & Very high & 168 & & 13.8 \\
\hline & High & 456 & & 37.4 \\
\hline & Moderate & 508 & & 41.7 \\
\hline & Light & 86 & & 7.1 \\
\hline \multirow{2}{*}{$\begin{array}{l}\text { Thought } \\
\text { to quit } \\
\text { job while } \\
\text { working } \\
\text { during } \\
\text { COVID-19 }\end{array}$} & Yes & 264 & & 21.7 \\
\hline & No & 954 & & 78.3 \\
\hline
\end{tabular}

${ }^{*} \mathrm{CHO}$, community health officer; NP, nurse practitioner; ASHA, ASHA worker; $\mathrm{HA}$, hospital attendant; $\mathrm{CHC}$, community health center, Lab, laboratories; HWC, health and wellness center 
sufficient hand hygiene facility, $73.6 \%$ received training from the working institute and $66 \%$ had received a complete supply of protective equipment in the clinical area (Table 2).

Approximately $18.6 \%$ of COVID-19 warriors were extremely fearful and concerned while working with COVID-19 patients and had a thought to quit the job. Significant association found between the thought of HCWs to quit the job and the factors; fear and concern, working area, and perceived support from the institute with a $p$ value of less than 0.05 which depicts its significant influence. Training about infection prevention and control of COVID-19, and the workload of healthcare workers was not found to be associated with their thought of quitting the job with a $p$ value of 0.07 . This suggests that workload is probably not the factor to influence a healthcare professional's thought process to leave the job (Table 3).

\section{Discussion}

In most instances, coronaviruses are believed to be transmitted from person-to-person via large respiratory droplets, contaminated fomites, and inhalation of aerosols ${ }^{13}$ but the transmissibility of the virus at different stages of the disease remain unclear. ${ }^{14}$ Beside this, there is increasing evidence of spreading COVID-19 from the persons with mild or no symptoms. ${ }^{15}$ The global outbreak of the COVID-19 imposes high-risk infection among frontline HCWs who are experiencing troublesome psychological situations including exhaustion due to overloaded service in pandemic and frightened of transmitting the disease to self and family. ${ }^{16}$

Table 2: Workplace preparedness of healthcare workers during COVID-19 pandemic $(n=1,218)$

\begin{tabular}{|c|c|c|c|}
\hline Variables & & Frequency & Percentage \\
\hline \multirow{5}{*}{$\begin{array}{l}\text { Prime source of } \\
\text { information about } \\
\text { COVID-19 }\end{array}$} & $\begin{array}{l}\text { Textbooks/ } \\
\text { journals }\end{array}$ & 99 & 8.1 \\
\hline & Social media & 250 & 20.5 \\
\hline & Newspapers & 73 & 6.0 \\
\hline & $\begin{array}{l}\text { E-sources/we- } \\
\text { binars }\end{array}$ & 304 & 25.0 \\
\hline & $\begin{array}{l}\text { Training } \\
\text { provided by } \\
\text { Institute }\end{array}$ & 492 & 40.4 \\
\hline \multirow{3}{*}{$\begin{array}{l}\text { Hand hygiene facility } \\
\text { available }\end{array}$} & Sufficient & 802 & 65.8 \\
\hline & Partial & 385 & 31.6 \\
\hline & Insufficient & 31 & 2.5 \\
\hline \multirow{2}{*}{$\begin{array}{l}\text { Received training for } \\
\text { infection prevention } \\
\text { and empowering } \\
\text { COVID-19 knowledge }\end{array}$} & Yes & 896 & 73.6 \\
\hline & No & 322 & 26.4 \\
\hline \multirow{5}{*}{$\begin{array}{l}\text { Perceived support } \\
\text { received from the } \\
\text { institute while work- } \\
\text { ing with patients of } \\
\text { COVID-19 }\end{array}$} & Excellent & 113 & 9.3 \\
\hline & Very good & 288 & 23.6 \\
\hline & Good & 489 & 40.2 \\
\hline & Fair & 223 & 18.3 \\
\hline & Poor & 105 & 8.6 \\
\hline \multirow[t]{3}{*}{$\begin{array}{l}\text { Availability of PPE in } \\
\text { clinical area }\end{array}$} & $\begin{array}{l}\text { Complete } \\
\text { supply }\end{array}$ & 804 & 66 \\
\hline & Partial supply & 353 & 29 \\
\hline & Short supply & 61 & 5 \\
\hline \multirow{3}{*}{$\begin{array}{l}\text { Perceived protection } \\
\text { by available PPE }\end{array}$} & Complete & 572 & 47 \\
\hline & Partial & 585 & 48 \\
\hline & Limited & 61 & 5 \\
\hline
\end{tabular}

As of March 18, a total of 167 confirmed cases of COVID-19 affecting 101 residents, 50 healthcare personnel, and 16 visitors were found in a long-term care facility in King County, Washington. ${ }^{17}$ The health authorities reported (published on March 15, 2020) that 3,019 Chinese health workers were infected by SARS-CoV-2, of whom, ten died. ${ }^{18}$ National e-Survey data presented that one-fourth (25\%) of HCWs experienced typical symptoms of COVID-19 infection who were in close contact with confirmed COVID-19 patients in their working center of Italy (Published May 2020). ${ }^{19}$ Though there is a paucity of accurate data, publications, and national situation report in India (country of residence of the authors) that provide information on the number of HCWs being affected on a daily basis but the Indian Journal of Medical Research had confirmed 1,073 cases among healthcare workers what could be the first official figures until 23 May. ${ }^{20}$ On July 1, 2020, national news confirmed 70 doctors had died during COVID-19 duty. ${ }^{21}$ These data highlight the essentiality of the support for healthcare workers in terms of PPE,

Table 3: Association between thought to quit job and selected variables of healthcare workers $(n=1,218)$

\begin{tabular}{|c|c|c|c|c|}
\hline & & \multicolumn{2}{|c|}{$\begin{array}{c}\text { Thought to quit the job } \\
\text { while working during } \\
\text { COVID-19 pandemic }\end{array}$} & \multirow[b]{2}{*}{$p$ value } \\
\hline \multicolumn{2}{|c|}{ Variables } & Yes & No & \\
\hline \multirow{4}{*}{$\begin{array}{l}\text { Fears and } \\
\text { concerns } \\
\text { while working } \\
\text { with COVID-19 } \\
\text { patients }\end{array}$} & Extreme & 49 (18.6\%) & 87 (9.2\%) & $0.0001^{*}$ \\
\hline & Very much & 87 (32.9\%) & 304 (31.8\%) & \\
\hline & $\begin{array}{l}\text { To some } \\
\text { extent }\end{array}$ & $86(32.6 \%)$ & $431(45.2 \%)$ & \\
\hline & Not much & $42(15.9 \%)$ & $132(13.8 \%)$ & \\
\hline \multirow[t]{7}{*}{ Area of work } & $\begin{array}{l}\text { Emergency/ } \\
\text { triage }\end{array}$ & $50(18.9 \%)$ & $258(27 \%)$ & $0.001^{*}$ \\
\hline & OPD & 79 (29.9\%) & 209 (21.9\%) & \\
\hline & $\begin{array}{l}\text { Isolation } \\
\text { ward }\end{array}$ & 89 (33.8\%) & $296(31 \%)$ & \\
\hline & OT & $4(1.6 \%)$ & $29(3 \%)$ & \\
\hline & $\begin{array}{l}\text { ICU/CCU/ } \\
\mathrm{HDU}\end{array}$ & $16(6 \%)$ & $48(5 \%)$ & \\
\hline & Ward & $16(6 \%)$ & 102 (10.7\%) & \\
\hline & $\begin{array}{l}\text { Others } \\
\text { (CHC, Lab, } \\
\text { HWC, Man- } \\
\text { agement) }\end{array}$ & $10(3.8 \%)$ & 12 (1.4\%) & \\
\hline \multirow[b]{2}{*}{$\begin{array}{l}\text { Received } \\
\text { training about } \\
\text { infection pre- } \\
\text { vention and } \\
\text { empowering } \\
\text { to COVID-19 } \\
\text { knowledge }\end{array}$} & Yes & $183(69.3 \%)$ & 713 (74.7\%) & 0.07 \\
\hline & No & 81 (30.7\%) & $241(25.3 \%)$ & \\
\hline \multirow{4}{*}{$\begin{array}{l}\text { Perceived } \\
\text { workload } \\
\text { while working } \\
\text { with COVID-19 } \\
\text { patients }\end{array}$} & Very high & 34 (12.8\%) & $134(14 \%)$ & 0.07 \\
\hline & High & $88(33.3 \%)$ & 368 (38.6\%) & \\
\hline & Moderate & 115 (43.6\%) & 393 (41.2\%) & \\
\hline & Light & 27 (10.3\%) & $59(6.2 \%)$ & \\
\hline \multirow{5}{*}{$\begin{array}{l}\text { Perceived } \\
\text { support from } \\
\text { the institute } \\
\text { while working } \\
\text { with patients } \\
\text { of COVID-19 }\end{array}$} & Excellent & 32 (12.2\%) & 81 (8.5\%) & $0.002^{*}$ \\
\hline & Very good & 49 (18.6\%) & $239(25 \%)$ & \\
\hline & Good & 104 (39.3\%) & 385 (40.4\%) & \\
\hline & Fair & $43(16.3 \%)$ & 180 (18.9\%) & \\
\hline & Poor & $36(13.6 \%)$ & 69 (7.2\%) & \\
\hline
\end{tabular}

*Significant $(p<0.05)$ 
hand hygiene facilities, reduced workload, psychological support, compensation, etc. and adequate attention toward their safety and health condition to keep them at their optimum health followed by the functional health system of the country.

Developing countries were already facing insufficient manpower, infrastructure (e.g., testing laboratories, intensive unit), finance for health expenditure and vital resources like ventilators, monitors, emergency drugs; and now this prodigious hardship remains for the shortage of the safety gears for corona warriors in healthcare. ${ }^{22}$ Infection prevention and control practices are of critical importance e.g., physical distancing, ${ }^{14}$ PPE (N95 respirators, surgical masks, face shield, gloves, eye protection, and gown), ${ }^{23,24}$ standard precautions (meticulous hand hygiene with sufficient soap or hand sanitizers and respiratory etiquette, surface decontamination, environmental cleaning, and practice safe waste management of COVID cases), ${ }^{24-26}$ the virological test of frontline healthcare staff as a priority and in timely manner, ${ }^{27}$ safe transfer of suspected or confirmed COVID-19 cases $^{24}$ along with self-isolation, social isolation and quarantine of HCWs after their working shift. Healthcare workers should receive training and strictly follow the guidelines e.g., putting on (donning) and safe removing (doffing) of PPE in the correct sequence ${ }^{4,23}$ as continuing medical education, competency building to healthcare workers has played a vital role to respond to such emergencies with quality assurance.

In Wuhan, the epicenter of the outbreak, medical professionals have reported using tape to patch up torn masks, reuse of eye goggles, and wrap their toes in domestic use plastic bags due to shortage of shoe covers. ${ }^{7,28}$ Doctors in Pakistan reported to have poor availability of PPE with only $37.4 \%$ having access to masks/ N95 respirator, $34.5 \%$ to gloves, $13.8 \%$ to face shields or goggles, and only $12.9 \%$ to full-suit/gown. Comparatively in the United States (US), $87.6 \%$ of doctors reported having access to masks/N95 respirators, $79.6 \%$ to gloves, $77.9 \%$ to face shields or goggles, and $50.4 \%$ to full-suit/gown in clinical area. ${ }^{29}$

In April 2020, another web-based international survey on the availability of PPE in ICU was performed among 2,711 responses where $58 \%$ of $\mathrm{HCW}$ s reported about the use of FFP2/N95 masks and $15 \%$ informed the use of surgical mask during routine care. At least one piece of standard PPE was unavailable for $52 \%$ of healthcare workers and $30 \%$ reported reusing of single-use PPE. ${ }^{30}$ In northern India, the present study findings revealed adequate, sometimes adequate, and short supplies of PPE for $66 \%, 29 \%$, and $5 \%$ of healthcare providers respectively at different levels of healthcare facility. The majority of HCWs (73.1\%) reported upright support received from the institute while working with COVID-19 patients. $\mathrm{HCWs}$ working in tertiary healthcare settings have reported a very good supply of PPE compared to secondary and primary healthcare settings. But in this present pandemic, it is need based to provide complete protection for all health workers irrespective of the level of healthcare.

A survey on hand hygiene facilities involving 46 clinical units of a large tertiary healthcare in northern Nigeria reported unavailability of written policy, alcohol-based hand rubs, hand drying facilities in the majority of the area. At least one hand-washing sink was in every unit but only $28 \%$ had flowing tap water all day while $72 \%$ utilized cup and bucket. ${ }^{31}$ The present study findings in northern India were quite different where $65.8 \% \mathrm{HCW}$ s had sufficient hand hygiene facilities, $31.6 \%$ had partial and $2.5 \%$ health professionals were dealing with unsatisfactory amenities. Now, it is anticipated from the institutional authority to identify the inadequate situations and work on them to reach the goal of $100 \%$ proper hand hygiene facilities at every healthcare institute along with an alarm to ensure frequent handwashing by HCWs.

In the fight against the 2019 novel coronavirus, when upgraded knowledge about COVID-19 is expected during the outbreak, Bhagavathula et al. found poor understanding of transmission and symptom onset of particular illness among health professionals. Most of the HCWs used social media to obtain information on COVID-19 and therefore urgent educational interventions were recommended..$^{32}$ In the present study, $20.5 \%$ of participants were using social sites as the main source of information and only $8.1 \%$ of participants relied on textbooks/journals. But the majority of participants $(73.6 \%)$ had received training from their working institute which was a really most useful standpoint during the pandemic.

Besides all those enormous pressure dealing by HCWs, factors including the high risk of infection, inadequate protection from contamination, overwork, frustration, discrimination, isolation, lack of contact with families, and exhaustion are psychological concerns faced by them..$^{33}$ More than $85 \%$ of HCWs feared self-infection with the virus ${ }^{34}$ and the prevalence of anxiety ${ }^{35}$ was found $12.5 \%$. In the present study, $18.6 \%$ of healthcare providers had extreme fear and had a thought to quit their job also. Therefore, it is important to ensure about well preparedness of healthcare workers with adequate equipment before addressing the geographical coverage because they need to be fit both physically and mentally with a sudden cascade of corona positive cases required specialized healthcare. Well preparedness will protect the functional healthcare services, source control, and mitigating the impact on vulnerable one.

\section{ConCLUSion}

In the situations of this unascertained disease and unforeseeable risks, healthcare professionals are scared to be infected and distressed, but they still eager to become a part of this battle, honest to their work assignment, focused on their tasks, and showed spirit toward the profession. All healthcare fraternity has integrated to work in this dilemma to flatten the pandemic curve. At this time, optimum physical and mental health of corona warriors should be the most concerning area for the institute as well as the government. Supplies of protective equipment, facilities for hygiene, training, counseling, and compensation are more required for the purpose. Keeping healthcare warriors safe and well through the crucial period by managing all the necessary steps is essential to retain the healthcare system functional.

\section{Limitation of the Study}

All the conveniently selected study participants were accessed by web-based, due to ensure social distancing and lockdown norms. It was more difficult to get responses from participants by repeated reminders to participants, and nonverbal expressions could not be obtained.

\section{ACKnOWLedgments}

Authors are thankful to all the healthcare workers for their cooperation in data collection and special thanks to $\mathrm{Dr}$ Ashok Kumar, Associate Professor and Chief Nursing Officer, AlIMS, Jodhpur; Mr. Harish Kajla, Nursing Officer, AlIMS, Delhi; 
Mr. Prakasha Mahala, Senior Nursing Officer (Emergency), AlIMS, Rishikesh; Mr. Chandu Raj, Senior Nursing Officer (Trauma and Critical Care), AlIMS, Rishikesh; Ms. Ankita Peter, Nursing Officer, LLRM Medical College, Meerut for their help in follow-up for the data collection.

\section{REFERENCES}

1. WHO Rolling updates on coronavirus disease (COVID-19). Available at: https://www.who.int/emergencies/diseases/novel-coronavirus-2019/ events-as-they-happen (accessed on June 13, 2020).

2. CDC. 2019 Novel Coronavirus, Wuhan, China. CDC. Available at https:// www.cdc.gov/coronavirus/2019-ncov/about/index.html. January 26, 2020; (accessed on June 14, 2020).

3. WHO. Coronavirus disease (COVID-19) Situation Report-144. Available at https://www.who.int/docs/default-source/coronaviruse/situationreports/20200612-covid-19-sitrep-144.pdf?sfvrsn=66ff9f4f_2 (accessed on June 13, 2020).

4. Nagesh S, Chakraborty S. Saving the frontline health workforce amidst the COVID-19 crisis: challenges and recommendations. J Glob Health 2020;10(1):010345. DOI: 10.7189/jogh-10-010345.

5. Centers for Disease Control and Prevention (CDC). Update: outbreak of severe acute respiratory syndrome - worldwide, 2003. MMWR Morb Mortal Wkly Rep 2003;52:269-272.

6. World Health Organization. Shortage of personal protective equipment endangering health workers worldwide. WHO, Geneva. 3 March 2020. Available at: https://www.who.int/news-room/detail/0303-2020-shortage-of-personal-protective-equipment-endangeringhealth-workers-worldwide (accessed on June 17, 2020).

7. Buckley C, Wee S-L, Qin A. China's doctors, fighting the Coronavirus, beg for masks. New York Times. 2020. Available: https://www. nytimes.com/2020/02/14/world/asia/china-coronavirus-doctors. html. (accessed June 12, 2020).

8. Papoutsi E, Giannakoulis VG, Ntella V, Pappa S, Katsaounou P. Global burden of COVID-19 pandemic on healthcare workers. ERJ Open Res 2020;6(2):00195-02020. DOI: 10.1183/23120541.00195-2020.

9. Pinner Harry Q, April 24, 2020, Covid-19: One in five healthcare workers could quit after pandemic unless urgent government action is taken, IPPR warns, https://www.ippr.org/news-and-media/pressreleases/covid-19-one-in-five-healthcare-workers-could-quit-afterpandemic-unless-urgent-government-action-is-taken-ippr-warns (accessed on June 16, 2020).

10. Kim T. Improving preparedness for and response to coronavirus disease 19 (COVID-19) in long-term care hospitals in Korea. Infect Chemother 2020;52(2):133-141. DOI: 10.3947/ic.2020.52.2.133.

11. Ministry of Health and Family Welfare Government of India. Available at: https://www.mohfw.gov.in/pdf/MeasuresUndertakenToEnsureSa fetyOfHealthWorkersDraftedForCOVID19Services.pdf (accessed on June 13, 2020).

12. World Health Organization. Consensus document on the epidemiology of severe acute respiratory syndrome (SARS); 2003. Available from URL: https://www.who.int/csr/sars/en/ WHOconsensus.pdf (accessed June 20 2020).

13. Galbadage T, Peterson BM, Gunasekera RS. Does COVID-19 spread through droplets alone? Front Public Health 2020;8:163. DOI: 10.3389/ fpubh.2020.00163.

14. European Centre for Disease Prevention and Control. Infection prevention and control for COVID-19 in healthcare settings - Second update. 31 March 2020. ECDC: Stockholm; 2020.

15. Rothe C, Schunk M, Sothmann P, Bretzel G, Froeschl G, Wallrauch C, et al. Transmission of 2019-nCoV infection from an asymptomatic contact in Germany. N Eng J Med 2020;382(10):970-971. DOI: 10.1056/ NEJMc2001468.

16. Grover S, Dua D, Sahoo S, Mehra A, Nehra R, Chakrabarti S. Why all COVID-19 hospitals should have mental health professionals: the importance of mental health in a worldwide crisis!. Asian J Psychiatr 2020;51:102147. DOI: 10.1016/j.ajp.2020.102147.
17. McMichael TM, Currie DW, Clark S, Pogosjans S, Kay M, Schwartz NG, et al. Epidemiology of covid-19 in a long-term care facility in king county, Washington. N Engl J Med 2020 382(21):2005-2011. DOI: 10.1056/NEJMoa2005412.

18. Xiang YT, Jin Y, Wang Y, Zhang Q, Zhang L, Cheung T. Tribute to health workers in China: a group of respectable population during the outbreak of the COVID-19. Int J Biol Sci 2020;16(10):1739-1740. DOI: 10.7150/ijbs.45135.

19. Felice C, Di Tanna GL, Zanus G, Grossi U. Impact of COVID-19 outbreak on healthcare workers in Italy: results from a national E-survey. J Community Health 2020;45(4):675-683. Available from https://doi. org/10.1007/s10900-020-00845-5.

20. Ghosh A, First official figures on Covid among healthcare workers in India - 1,073 cases until 23 May [Internet]. 2020 June 22 [cited 2020 July 23]; The Print: Health. Available from https://theprint.in/health/ first-official-figures-on-covid-among-healthcare-workers-in-india1073-cases-until-23-may/446586/.

21. Tandon A, At least 70 Indian doctors have died so far while on Covid duty [Internet]. 2020 July 1 [cited 2020 July 23]; Tribune News Service: Voice of the people. Available from: https://www.tribuneindia.com/ news/nation/at-least-70-indian-doctors-have-died-so-far-while-oncovid-duty-107081.

22. Peters DH, Garg A, Bloom G, Walker DG, Brieger WR, Rahman MH. Poverty and access to health care in developing countries. Ann N Y Acad Sci 2008;1136(1):161-171. DOI: 10.1196/annals.1425.011.

23. European Centre for Disease Prevention and Control (ECDC). Guidance for wearing and removing personal protective equipment in healthcare settings for the care of patients with suspected or confirmed COVID-192020 [cited 8 March 2020]. Available from: https:// www.ecdc.europa.eu/en/publications-data/guidance-wearing-andremoving-personal-protective-equipment-healthcare-settings.

24. World Health Organization (WHO). Rational use of personal protective equipment for coronavirus disease2019 (COVID-19) 2020 [updated 27 February 2020; cited 8 March2020]. Available from: https://apps. who.int/iris/bitstream/handle/10665/331215/WHO-2019-nCovIPCPPE_use-2020.1-eng.pdf.

25. US Centers for Disease Control and Prevention (CDC). Strategies to Prevent the Spread of COVID-19 in Long-Term Care Facilities (LTCF) 2020 [updated 1 Mach 2020; cited 8 March 2020]. Available from: https://www.cdc.gov/coronavirus/2019-ncov/healthcare-facilities/ prevent-spread-in-long-term-care-facilities.html.

26. World Health Organization (WHO). Hand Hygiene in Outpatient and Home-based Care and Long-term Care Facilities 2012 [cited 8 March 2020]. Available from: https://apps.who.int/iris/bitstream/handle/10 665/78060/9789241503372_eng.pdf?sequence $=1$.

27. European Centre for Disease Prevention and Control. Case definition and European surveillance for COVID-19, as of 2 March 2020 Stockholm: ECDC; 2020. Available from: https://www.ecdc.europa. eu/en/case-definition-and-european-surveillance-human-infectionnovel-coronavirus-2019-ncov.

28. Chen A, Video of Female Medics in China Having Their Heads Shaved Sparks Backlash Over Propaganda in the Coronavirus Fight. TIME. 2020. Available: https://time.com/5788592/weibo-womencoronavirus/. Accessed: 14 April 2020.

29. Ahmed J, Malik F, Bin Arif T, Majid Z, Chaudhary MA, Ahmad J, et al. Availability of personal protective equipment (PPE) among US and Pakistani doctors in COVID-19 pandemic. Cureus 2020;12(6):e8550. DOI: 10.7759/cureus.8550.

30. Tabah A, Ramanan M, Laupland KB, Buetti N, Cortegiani A, Mellinghoff $\mathrm{J}$, et al. Personal protective equipment and intensive care unit healthcare worker safety in the COVID-19 era (PPE-SAFE): an international survey. J Crit Care 2020;59:70-75. DOI: 10.1016/j. jcrc.2020.06.005.

31. Onyedibe KI, Shehu NY, Pires D, Isa SE, Okolo MO, Gomerep SS, et al. Assessment of hand hygiene facilities and staff compliance in a large tertiary health care facility in northern Nigeria: a cross sectional study. Anti Microb Resist Infect Control 2020;9(1):30. Available on: https:// doi.org/10.1186/s13756-020-0693-1. 
32. Bhagavathula AS, Aldhaleei WA, Rahmani J, Mahabadi MA, Bandari DK. Knowledge and perceptions of COVID-19 among health care workers: cross-sectional study. JMIR Public Health Surveill 2020;6(2):e19160. DOI: 10.2196/19160.

33. Kang L, Li Y, Hu S, Chen M, Yang C, Yang BX, et al. The mental health of medical workers in Wuhan, China dealing with the 2019 novel coronavirus. Lancet Psychiatr 2020;7(3):e14. Available at: https://doi. org/10.1016/S2215-0366(20)30047-X.
34. Zhang M, Zhou M, Tang F, Wang Y, Nie H, Zhang L, et al. Knowledge, attitude, and practice regarding COVID-19 among healthcare workers in Henan, China. J Hosp Infect 2020;105(2):183-187. DOI: 10.1016/j. jhin.2020.04.012

35. Liu CY, Yang Y, Zhang XM, Xu X, Dou Q-L, Zhang W-W, et al. The prevalence and influencing factors in anxiety in medical workers fighting COVID-19 in China: a cross-sectional survey. Epidemiol Infect 2020;148:e98. DOI: 10.1017/S0950268820001107. 